\title{
Influence of the pre-treatment of nanofibers obtained from mushrooms on the mechanical properties of the paper*)
}

\author{
Mizan Izzati Mat Zin 1) (ORCID ID: 0000-0003-3667-9521), Muhammad Azammuddin Suratem ${ }^{1)}$, \\ Wan Mohd Fazli Wan Nawawi ${ }^{1)}$ **) $(0000-0002-8663-0542)$ \\ DOI: dx.doi.org/10.14314/polimery.2021.9.3
}

\begin{abstract}
The influence of the pre-treatment process (freezing, drying) on the tensile properties of chitin paper obtained from nanofibers of three commercial species of fungi: oyster mushrooms (P. ostreatus), enoki (F. velutipes) and shiitake (L. edodes) was investigated. The chitin nanofibers were extracted by a mild alkaline process. The highest tensile strength was observed for paper obtained from fresh mushrooms fibers, which may result from the lack of the chitin fiber modification. Freezing and drying processes have been found to reduce the strength of the paper, possibly due to ice crystal formation and the keratinization effect of the nanofibers, respectively. The paper obtained from enoki fungus nanofibers was characterized by the highest tensile strength, which may be due to the very long fiber. However, in terms of elongation at break, the best results were obtained with oyster mushrooms nanofibers, probably due to the relatively shorter chitin fiber. The long enoki nanofibers can therefore be used as a good reinforcement of the paper.
\end{abstract}

Keywords: chitin nanofiber, chitin paper, fungal-based chitin.

\section{Wpływ obróbki wstępnej nanowłókien pozyskanych z grzybów na właściwości mechaniczne papieru}

\begin{abstract}
Streszczenie: Zbadano wpływ procesu obróbki wstępnej (zamrażanie, suszenie) na właściwości mechaniczne przy rozciąganiu papieru chitynowego otrzymanego z nanowłókien trzech komercyjnych gatunków grzybów: boczniaka ostrygowatego (P. ostreatus), enoki (F. velutipes) i shiitake (L. edodes). Nanowłókna chitynowe wyekstrahowano w łagodnym procesie alkalicznym. Największą wytrzymałość na rozciąganie zaobserwowano dla papieru otrzymanego z włókien świeżych grzybów, co może wynikać z braku modyfikacji włókna chitynowego. Stwierdzono, że procesy zamrażania i suszenia zmniejszają wytrzymałość papieru, co jest prawdopodobnie spowodowane odpowiednio tworzeniem się kryształków lodu i efektem rogowacenia nanowłókien. Otrzymany z grzybów enoki papier charakteryzował się największą wytrzymałością na rozciąganie, co może wynikać z dużej długości tego włókna. Jednak pod względem wydłużenia przy zerwaniu najlepsze wyniki uzyskano dla grzybów boczniaka, prawdopodobnie ze względu na stosunkowo krótkie włókno chitynowe. Długie nanowłókna enoki mogą więc być stosowane jako dobre wzmocnienie papieru.
\end{abstract}

Słowa kluczowe: nanowłókna chitynowe, papier chitynowy, chityna na bazie grzybów.

Research in chitin field had attracted many researcher by the idea of in finding an alternative from waste (crustacean shell) bio-based nanofiber for biodegradable polymer [1]. Chitin is a polysaccharide fiber with a subunit of glucosamine and an acetyl group attached to the amine group which can be extracted from natural resources,

\footnotetext{
1) Department of Biotechnology Engineering, Kuliyyah of Engineering, International Islamic University Malaysia (IIUM), Jalan Gombak, 53100 Kuala Lumpur, Malaysia.

*) Material contained in this article was presented at the $1^{\text {st }} \mathrm{Ma}-$ laysia International Conference on Nanotechnology \& Catalysis (MICNC 2021), 1-3 September 2021, Malaya, Malaysia.

**) Author for correspondence: wanmohdfazli@iium.edu.my
}

including crustacean shells and fungi cell walls [2]. The extraction of chitin from fungal cell walls has become an emerging topic nowadays, since the acid treatment can be bypassed due to an insignificant amount of minerals [3]. Although demineralization is not necessary for fungal chitin extraction, in 2011, Ifuku and coworkers still included acid treatment $(2 \mathrm{M} \mathrm{HCl}$ for two days at room temperature) in fungal chitin extraction from five different mushrooms species [4]. Erdogan, Kaya [5] also treated the mushrooms with $2 \mathrm{M} \mathrm{HCl}$ but only for $15 \mathrm{~h}$ at $60^{\circ} \mathrm{C}$. Later, in 2018 , Hassainia and his team extracted A. bisporus mushroom without a demineralization process. Nawawi, Lee [6] also proved that extracting chitin from $A$. bisporus mushroom using a mild condition with- 
out demineralization is sufficient for fungal chitin extraction. Indeed, it recorded a higher chitin yield. Recent studies on fungal chitin also bypass the demineralization step in the extraction process [7, 8].

Moreover, the nature of the fungal chitin structure that is covalently linked with alkali-insoluble glucan contributes to better mechanical performance compared to that of chitin from crustacean [6]. The covalent interaction between chitin and glucan has been proven by chemical hydrolysis and enzymatic digestion $[9,10]$, disruption of the gene [11] and solid-state NMR [12]. The idea for the first two approaches is to change the solubility characteristics of glucan by degrading the chitin-glucan structure. The association of glucan with chitin makes it insoluble in alkali [13]. When this alkali-insoluble fraction is treated with glucan degrading enzyme (glucanase), about $16 \%$ of glucan remains in the insoluble form [14]. However, when the same fraction is treated with chitinase (chitin degrading enzyme), the glucan is completely dissolved in an alkali $[10,11]$. These results proved the crosslink interaction between chitin and glucan in fungal source.

In previous studies, fungal chitin from mushrooms was used for the fabrication of chitin paper $[6,15,16]$. Typically, this chitin paper was studied for the mechanical properties to widen its applications such as in composites and water treatment. In water treatment, chitin paper can be used as a filtration membrane. Yousefi, Jones [17] explored the possibility of using fungal chitin paper from A.bisporus as an ultrafiltration membrane for aqueous solutions and organic solvents.

Previous studies showed potential applications of fungal chitin from fresh mushrooms. But, compared to crustacean shell, the commercialization purpose for chitin from mushrooms might be difficult since fresh mushrooms are easily spoilt due to high water content. The high water content in mushrooms promotes the microbial growth which would degrade the mushrooms. Thus, to enhance their shelf life, preservation techniques such as drying and freezing are applied to the mushrooms. Drying is the traditional way to preserve mushrooms by preventing the growth of microorganisms and reducing moisture-mediated reactions [18]. In the ancient times, drying through natural air convection or sunlight radiation were mostly pioneered for food preservation. Dried food products, as a result, has significantly reduced water content compared to their fresh conditions which is useful for food storage, packaging and transport [19]. On the other hand, a low temperature could also weaken enzymatic and microbial activities on the mushrooms [20]. Since these preservation techniques might affect the quality of mushrooms, therefore, the mechanical properties of extracted fungal chitin-related structures such as paper might also be affected.

Therefore, the effect of different pre-treatment processes i.e. freezing, drying and no pre-treatment (or fresh extraction) on the mechanical properties of chitin papers derived from three different mushroom species (oyster mushroom Pleurotus ostreatus, enoki mushroom Flammulina velutipes, and shiitake mushroom Lentinula edodes) were investigated. This study used mild extraction process which does not require acid solutions for demineralization purposes unlike the method used for crustacean shells. The physical characterization is conducted by analyzing the mechanical properties data as suggested by Chen, Sun [21].

\section{EXPERIMENTAL PART}

\section{Materials}

Three different mushroom species; enoki (F. velutipes), oyster (P. ostreatus) and shitake (L. edodes) were purchased from local supermarket. Sodium hydroxide (Merck, pellet) was used for chitin extraction.

\section{Pre-treatment of mushrooms}

The initial dry weight of total mushrooms used for extraction was $30 \mathrm{~g}$. Based on dry weight $\%$ of the mushrooms (shiitake $\sim 20 \%$, oyster and enoki $\sim 10 \%$ ), the total weight of mushrooms used were $150 \mathrm{~g}$ for shiitake and $300 \mathrm{~g}$ for both oyster and enoki mushrooms (Equation 1).

Total weight of mushrooms used $=$ $=30 \mathrm{~g} /$ dry weight $\%$ of mushrooms

The mushrooms were pre-treated differently and accordingly (freezing and drying). The fresh mushrooms without any pretreatment were used for control. The fresh mushrooms were stored at $4^{\circ} \mathrm{C}$ and should be used within three days to prevent spoilage. For freezing pre-treatment, the mushroom were frozen at $-20^{\circ} \mathrm{C}$ for at least $24 \mathrm{~h}$ while for drying pre-treatment, the mushrooms were dried in an oven at $60^{\circ} \mathrm{C}$ for $24 \mathrm{~h}$ and finely ground in a grinder (150 $\mu \mathrm{m}$ particle size). Based on the ratio of mushrooms dry weight to the total solution volume of 1:50, 1.5 L total solution was required during extraction process.

\section{Chitin nanofiber extraction}

Prior to extracting, the untreated fresh mushrooms and the frozen sample were washed with tap water for three times and rinsed with distilled water. Next, the mushrooms were blended for $5 \mathrm{~min}$ in the high-speed blending mixer (Vita Mixer Innofood, SX766). For the dried sample, the washing step was not necessary. Distilled water was added to the blended mushrooms (or mushroom powder for dried sample) until the total volume was $1.5 \mathrm{~L}$. The extraction process started with hot water extraction $\left(85^{\circ} \mathrm{C}, 1 \mathrm{~h}\right)$ in stirring conditions using magnetic hot plate (IKA ${ }^{\circledR}, \mathrm{G}-\mathrm{MAG}$ HS 7) to remove water-soluble glucans. The extract was then filtered using white cotton filter cloth (EBC082, Nagoya Textile) and vacuum 
pump (VALUE, VE 115N). The filtration cake obtained was soaked and stirred in an alkaline solution $(1 \mathrm{M}$ $\mathrm{NaOH}, 65^{\circ} \mathrm{C}, 3 \mathrm{~h}$ ) with a total volume of $1.5 \mathrm{~L}$ to remove protein matrix encapsulating the chitin nanofibers and alkali-soluble glucans. Then, it was neutralized with excess water until the universal test paper indicated $\mathrm{pH}$ 7 before being further rinsed with distilled water. The neutralized chitin was suspended with distilled water $(0.7 \% \mathrm{w} / \mathrm{v})$ and dispersed homogeneously by stirring for $30 \mathrm{~min}$ at room temperature before $5 \mathrm{~min}$ final blending.

\section{Preparation of chitin paper}

The required volume of $0.7 \%(\mathrm{w} / \mathrm{v})$ chitin suspensions from each sample were calculated using Equation 2 so that the final paper specifications (grammage $-80 \mathrm{gsm}$; diameter - $110 \mathrm{~mm}$, thickness - $0.09 \pm 0.01 \mathrm{~mm}$ ) were achieved.

$$
\mathrm{V}_{\text {suspension }}=(\text { Area of paper }) \cdot(80 \mathrm{gsm}) / 0.7 \%
$$

The required volume of $0.7 \%(\mathrm{w} / \mathrm{v})$ chitin suspensions were filtered through cellulose filter paper (Sartorius, 1288) by a vacuum pump (GAST (USA), Lab Models) for an hour. The filter cake was peeled off and pressed between blotting paper before pre-drying in the oven at $120^{\circ} \mathrm{C}$ for $5 \mathrm{~min}$ to remove excess of water. Then, the sample was dried in the oven at $120^{\circ} \mathrm{C}$ for an hour under $5 \mathrm{~kg}$ weight after exchanging the blotting paper with the new one. To prevent shrinkage, the sample was left overnight at room temperature under $5 \mathrm{~kg}$ weight.

\section{Mechanical properties of chitin paper}

The mechanical properties of paper for all samples were determined using a universal tensile machine (Shimadzu AGS-X) based on ASTM D828-97 (1 mm/min crosshead speed, $30 \mathrm{~mm}$ gauge length and 2 bar grip pressure). The dimension of the samples was $60 \times 10 \mathrm{~mm}$. Prior to the test, the gripping zone of the samples was secured with cardboards using epoxy (Araldite ${ }^{\circledast}$ Standard). The test was repeated five times.

\section{RESULTS AND DISCUSSION}

\section{Chitin extraction process}

The extraction of chitin in this study was performed using mild extraction process to preserve the quality of chitin fibers. Acid treatment is known to degrade chitin chain [22]. Therefore, since mushrooms contain an insignificant amount of minerals [3], acid treatment could be bypassed. On the other hand, peroxide or chlorinated bleaching was not carried out in this study because it might cause a depolymerization effect on biopolymer chain [23]. Fungal chitin, which is covalently linked with branched glucan polymer, is more prone to chemical attacks during the decolorization process. Chitin-glucan structure in fungal chitin is known to improve the toughness and strength of papers [6]. Thus, to maintain this chitin-glucan structure, no bleaching treatment was conducted throughout the study. Figure 1 shows chitin papers without bleaching treatment. The brownish color a)

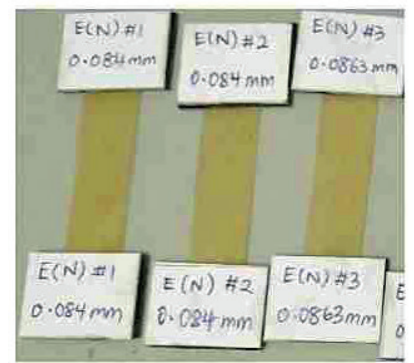

b)



c)

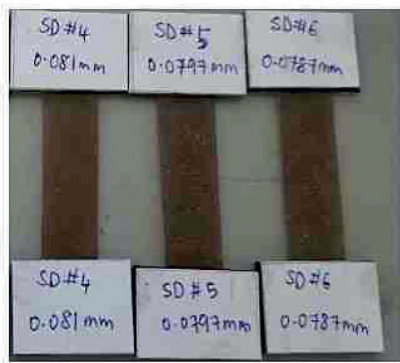

Fig 1. Chitin paper from: a) enoki, b) oyster, c) shitake mushrooms without bleaching treatment

$\mathrm{T}$ a b 1 e 1. Selected mechanical properties of chitin paper from fungi species with different pre-treatment processes

\begin{tabular}{|c|c|c|c|c|c|}
\hline Pre-treatment & $\sigma_{\mathrm{T}^{\prime}} \mathrm{MPa}$ & $\varepsilon_{\mathrm{T}^{\prime}} \%$ & E, GPa & $\mathrm{U}_{\mathrm{r}^{\prime}} \mathrm{MJ} / \mathrm{m}^{3}$ & Species \\
\hline \multirow{3}{*}{ No treatment } & $48.3 \pm 6.0$ & $5.1 \pm 1.1$ & $2.65 \pm 0.56$ & $1.8 \pm 0.5$ & Oyster \\
\hline & $67.0 \pm 3.2$ & $3.5 \pm 0.6$ & $4.44 \pm 0.31$ & $1.6 \pm 0.4$ & Enoki \\
\hline & $55.4 \pm 2.5$ & $2.9 \pm 0.3$ & $3.73 \pm 0.34$ & $1.0 \pm 0.2$ & Shiitake \\
\hline \multirow{3}{*}{ Freezing } & $45.6 \pm 1.3$ & $6.2 \pm 0.9$ & $2.33 \pm 0.11$ & $2.2 \pm 0.4$ & Oyster \\
\hline & $51.0 \pm 2.0$ & $4.1 \pm 0.7$ & $2.83 \pm 0.05$ & $1.4 \pm 0.3$ & Enoki \\
\hline & $43.1 \pm 2.3$ & $3.4 \pm 0.8$ & $2.71 \pm 0.49$ & $1.0 \pm 0.3$ & Shiitake \\
\hline \multirow{3}{*}{ Drying } & $43.8 \pm 3.6$ & $3.6 \pm 0.7$ & $2.87 \pm 0.22$ & $1.1 \pm 0.3$ & Oyster \\
\hline & $48.5 \pm 8.3$ & $1.9 \pm 0.8$ & $3.60 \pm 0.32$ & $0.6 \pm 0.4$ & Enoki \\
\hline & $37.0 \pm 3.6$ & $2.1 \pm 0.4$ & $2.78 \pm 0.42$ & $0.5 \pm 0.2$ & Shiitake \\
\hline
\end{tabular}

where: $\sigma_{\mathrm{T}}$ - tensile strength, $\varepsilon_{\mathrm{T}}$ - elongation at break, E - Young's modulus, $\mathrm{U}_{\mathrm{r}}$ - toughness or resilience 

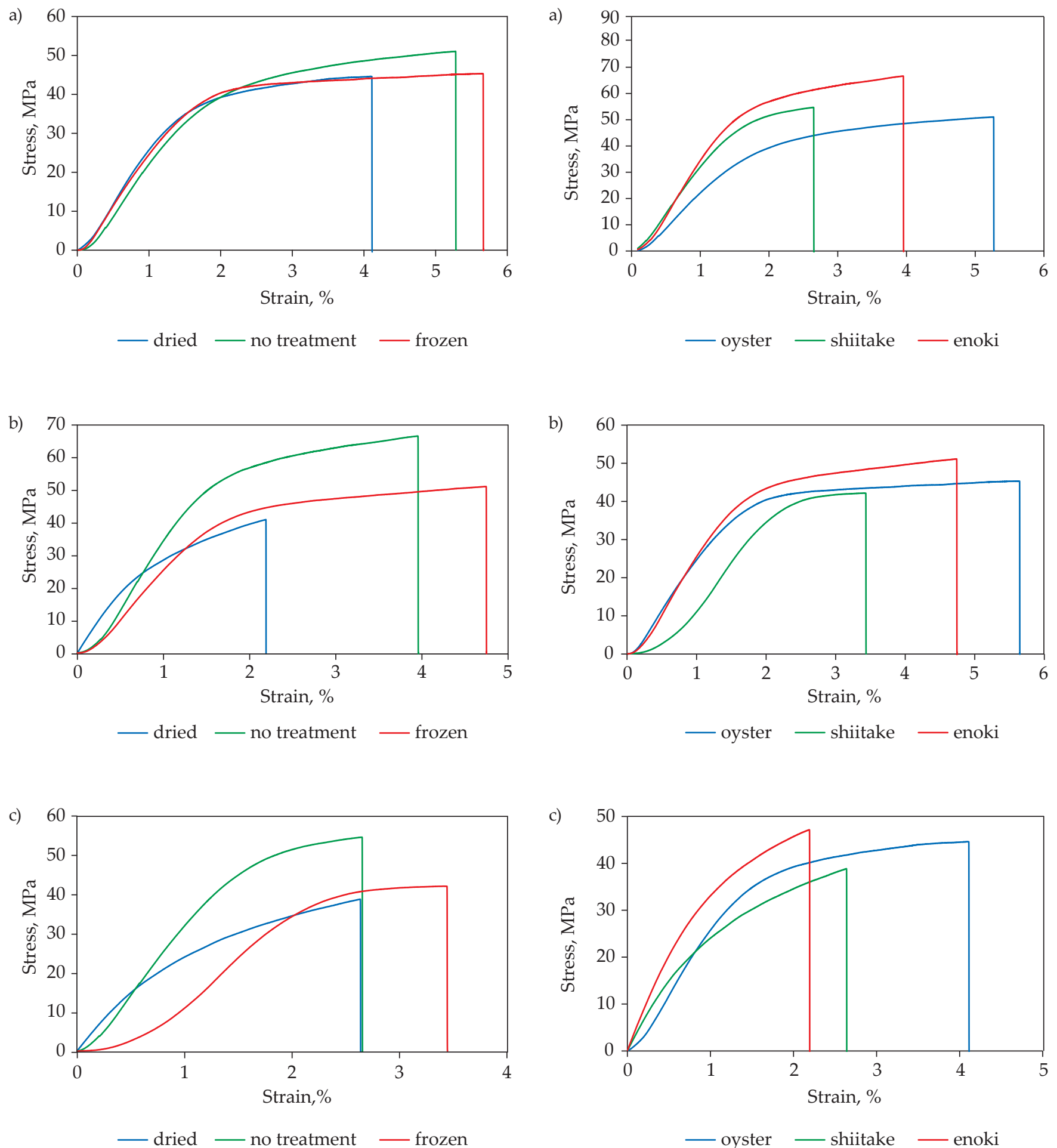

Fig. 2. Stress-strain curves of chitin paper from: a) oyster, b) enoki, c) shitake mushrooms

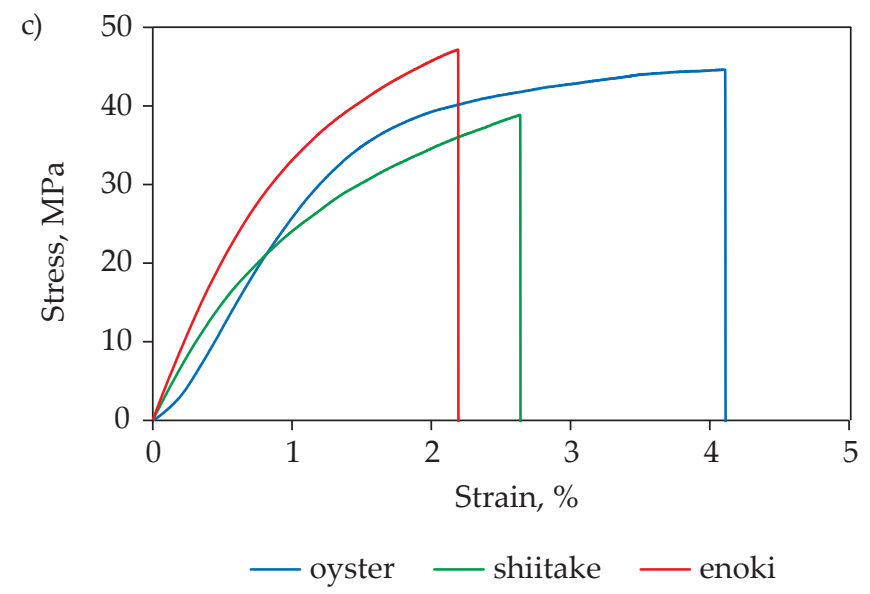

Fig. 3. Stress-strain curves of fungal chitin paper for different pre-treatments : a) no treatment, b) frozen, c) dried

of papers is caused by the accumulation of fungal pigment on the surface of the mature mycelium $[24,25]$. This fungal pigment is known as melanin, which is a polymer of phenolic compounds [26, 27]. The color of chitin paper from shitake is darker possibly because the intensity of melanin is higher.

\section{Mechanical properties of chitin paper}

The mechanical properties of chitin paper from oyster, enoki and shiitake mushrooms with different pre-treatment processes are presented in Table 1 . The overall data shows that the papers from each kind of mushrooms 
without any pre-treatment process exhibit the best results compared to that of frozen and dried mushrooms.

For a better illustration of these comparisons, the Fig. 2 illustrates the stress-strain plots of chitin papers from oyster, enoki and shitake mushrooms with three different pre-treatment. For oyster mushrooms, the tensile strenght for the sample without treatment showed an increase of $6 \%$ and $10 \%$ compared to frozen and dried samples, respectively. But, for the toughness, the sample from frozen oyster mushrooms exhibited the highest result. As for both enoki and shitake, the tensile strength of the samples without treatment increased almost half the value of the dried samples. Thus, it is plausible to say that the samples without pre-treatment enhance the tensile strength while the process of freezing enhances the toughness of the extracted chitin, but reduces the modulus.

The formation of ice crystal during the freezing process is related to water distribution in food materials [28]. This ice crystal causes damage to cell structure due to a change of cytoplasm water which leads to a reduction of cell stiffness. Hence, the mechanical properties change [29]. This might be the reason why the modulus of frozen samples for all mushrooms decreases. On the other hand, the mechanical properties of dried samples might be affected by the hornification effect. During the drying process of mushrooms, the fiber structure stiffens and the fiber volume shrinks which causes structural changes [30]. Both freezing and drying cause structural changes that affect the mechanical properties. We also presume that using fresh mushrooms does not modify their chitin structure. Thus, gives a better tensile strength.

Fig. 3 compares the mechanical performance of fungal chitin paper for different pre-treatments. For all pre-treatments, the chitin paper from enoki recorded the highest values for tensile strength and modulus. This possibly was caused by the long structure of chitin in enoki mushroom. Since chitin is located in the cell wall of mushrooms [15], therefore, the longer structure of enoki can preserve the initial structure of chitin. A longer fiber was proven to improve the mechanical properties of a material [31]. However, in terms of toughness, the samples from oyster mushrooms for all treatments demonstrated the highest result. This result is probably because the chitin fiber in oyster mushrooms is relatively smaller compared to that of enoki and shitake mushrooms. Thus, it can form a denser fibrous network that can sustain higher external loading.

\section{CONCLUSIONS}

Oyster, enoki and shiitake mushrooms were used as the source of fungal chitin. The mushrooms were subjected to three different treatments before being extracted using a mild alkaline process and the extracted chitin was used to fabricate chitin paper. Chitin papers from all fresh mushrooms have the best tensile strength, which might be due to the absence of chitin structure modification. The reduction of tensile properties in frozen and drying samples was probably caused by the ice crystal formation and hornification effect, respectively. Among oyster, enoki and shiitake mushrooms, the samples from enoki mushroom give the best tensile strength, possibly due to the longer chitin structure in that mushroom. However, in terms of toughness, oyster mushroom gives the best result probably due to relatively smaller chitin fiber. The results suggested that for further commercialization purposes, using frozen mushrooms to prevent spoilage will not cause big differences in the mechanical properties compared to the fresh mushrooms. This study also opens the possibility of fungal chitin from mushrooms to be used as a reinforcement in the bio-based composite manufacturing process. For the application where tensile strength is important, we suggest to use enoki mushroom without treatment. While for better toughness application, the frozen oyster mushroom is suggested.

\section{ACKNOWLEDGEMENTS}

The authors acknowledge the Ministry of Education Malaysia and International Islamic University Malaysia for providing financial support to this project FRGS/1/2018/TK05/ UIAM/03/3. The authors would also like to thank Ir. Mat Zin bin Hussain for his willingness to proofread this manuscript.

\section{REFERENCES}

[1] Guo Y., Duan B., Zhou J. et al.: Cellulose 2014, 21, 1781. https://doi.org/10.1007/s10570-014-0164-z

[2] Wysokowski M., Petrenko I., Stelling A. et al.: Polymers 2015, 7, 235.

https://doi.org/10.3390/polym7020235

[3] Khor E.: "The Sources and Production of Chitin" in Chitin: Fulfilling a Biomaterials Promise, 2001, Elsevier. p. 63. https://doi.org/10.1016/b978-008044018-7/50005-1

[4] Ifuku, S., Nomura, R., Morimoto, M. et al.: Materials (Basel) 2011, 4, 1417. https://doi.org/10.3390/ma4081417

[5] Erdogan S., Kaya M., Akata I.: “Chitin extraction and chitosan production from cell wall of two mushroom species (Lactarius vellereus and Phyllophora ribis)", Materials from The $6^{\text {th }}$ International Advances in Applied Physics and Materials Science Congress \& Exhibition, 1-3 June 2016, 1809. https://doi.org/10.1063/1.4975427

[6] Nawawi W., Lee K.-Y., Kontturi E. et al.: ACS Sustainable Chemistry \& Engineering 2019, 7, 6492. https://doi.org/10.1021/acssuschemeng.9b00721

[7] Xiao J., Zhang M., Wang W. et al.: Int J Biol Macromol 2020, 164, 4628. https://doi.org/10.1016/j.ijbiomac.2020.09.073

[8] Salehinik F., Behzad T., Zamani, A. et al.: Int J Biol Macromol 2021, 167, 1126.

https://doi.org/10.1016/j.ijbiomac.2020.11.066 
[9] Kollar R., Reinhold B.B., Petrakova E. et al.: The Journal of Biological Chemistry 1997, 272, 17762. https://doi.org/10.1074/jbc.270.3.1170

[10] Sietsma J.H., Wessels J.G.H.: Journal of General Microbiology 1979, 114, 99. https://doi.org/10.1099/00221287-114-1-99

[11] Hartland R.P., Vermeulen C.A., Klis F.M. et al.: Yeast 1994, 10, 1591. https://doi.org/10.1002/yea.320101208

[12] Heux L.B., J., Desbrieres J., Versali M.F, Rinaudo M.: Biomacromolecules 2000, 1, 746. https://doi.org/10.1021/bm000070y

[13] Gaderer R., Seidl-Seiboth V., Kappel L.: Current Biotechnology 2017, 6, 178. https://doi.org/10.2174/2211550105666160330205801

[14] Sietsma J.H., Wessels J.G.H.: Biochimica et Biophysica Acta, 1977, 496, 225. https://doi.org/10.1016/0304-4165(77)90131-3

[15] Haneef M., Ceseracciu L., Canale C. et al.: Scientific Reports 2017, 7, 41292. https://doi.org/10.1038/srep41292

[16] Jones M.P., Weiland K., Kujundzic M. et al.: Biomacromolecules 2019, 20, 3513. https://doi.org/10.1021/acs.biomac.9b00791

[17] Yousefi N., Jones M.P., Bismarck A. et al.: Carbohydrate Polymers 2021, 253, 117273. https://doi.org/10.1016/j.carbpol.2020.117273

[18] Tian Y., Zhao Y., Huang J. et al.: Food Chem 2016, 197, 714. https://doi.org/10.1016/j.foodchem.2015.11.029

[19] Berk Z.: "Freeze drying (lyophilization) and freeze concentration" in Food Process Engineering and Technology, 2018. p. 567-581. https://doi.org/10.1016/B978-0-12-812018-7.00023-3

[20] Li T., Lee J.-W., Luo L. et al.: Applied Biological Chemistry 2018, 61, 257. https://doi.org/10.1007/s13765-018-0354-8

[21] Chen B., Sun K., Ren T.: European Polymer Journal 2005, 41, 453.

https://doi.org/10.1016/j.eurpolymj.2004.10.015

[22] Percot A., Viton C., Domard A.: Biomacromolecules 2003, 4, 12.

https://doi.org/10.1021/bm025602k

[23] Topalovic T., Nierstrasz V.A., Bautista L. et al.: Cellulose 2007, 14, 385. https://doi.org/10.1007/s10570-007-9120-5

[24] Yoo S.I., Lee H.Y., Markkandan K. et al.: BMC Genomics 2019, 20, https://doi.org/10.1186/s12864-019-5509-4

[25] Yan D., Liu Y., Rong C. et al.: Fungal Biology 2020, 124, 135. https://doi.org/10.1016/j.funbio.2019.12.008

[26] Belozerskaya T.A., Gessler N.N., Aver'yanov A.A.: "Melanin Pigments of Fungi" in Fungal Metabolites, 2017. p. 263-291. https://doi.org/10.1007/978-3-319-25001-4_29

[27] Plonka P.M., Grabacka M.: Acta Biochimica Polonica 2006, 53, 429. https://doi.org/10.18388/abp.2006_3314

[28] Li D., Zhu Z., Sun D.-W.: Trends in Food Science \& Technology 2018, 75, 46. https://doi.org/10.1016/j.tifs.2018.02.019

[29] Ragoonanan V., Less R., Aksan A.: Cryobiology 2013, 66, 96. https://doi.org/10.1016/j.cryobiol.2012.10.008

[30] Fernandes Diniz J.M.B., Gil M.H., Castro J.A.A.M.: Wood Science and Technology 2004, 37, 489. https://doi.org/10.1007/s00226-003-0216-2

[31] Yu M., Zhang H., Liu Z. et al.: Fibers and Polymers 2019, 20, 1726. https://doi.org/10.1007/s12221-019-1171-3

Received 14 VIII 2021 